\title{
CLINICAI. PHARMACOLOGY OF BRETYLIUM TOSYLATE: PRELIMINARY OBSERVATIONS
}

\author{
James Conway* \\ Department of Internal Medicine, Universily of Michigan, Ann Arbor, Mich.
}

The introduction of a new quaternary ammonium compound, bretylium tosylate, ${ }^{1,2}$ which selectively blocks transmission in postganglionic sympathetic nerve fibers, may be an important advance in the treatment of hypertension and peripheral vascular diseases. Of equal interest is the opportunity it provides for the evaluation of the role of the sympathetic nervous system in the pathogenesis of these diseases.

An attempt has been made, therefore, to study the ability of bretylium to block sympathetically mediated reflexes in man, and to determine the changes it produces in the circulation. The effect on the blood pressure after parenteral and oral administration has also been assessed.

\section{Methods}

The effects of bretylium tosylate ${ }^{2}$ have been studied in twenty patients (17 hypertensives and 3 normotensives). Injections were made in small quantities, approximately $12.5 \mathrm{mg}$., until a dose of $100 \mathrm{mg}$. was given over a $10-\mathrm{min}$. period. Measurements have been made of skin temperature (11 subjects), digital blood flow (9 subjects), forearm blood flow (13 subjects), and cardiac output (5 subjects). The skin temperature measurements were made with thermocouples applied to the dorsum of the hand and foot and, on some occasions, another on the trunk. Finger blood flow measurements were made with a conventional air-filled plethysmograph applied to the terminal phalanx, with venous occlusion applied to the same digit. The forearm flow was measured by a Whitney mercury-in-rubber strain gauge, ${ }^{3}$ placed on the upper one third of the forearm, with venous occlusion applied by means of a sphygmomanometer cuff above the elbow. Another cuff at the wrist excluded the circulation from the hand. The room temperature in these studies varied from 72 to $76^{\circ} \mathrm{F}$.

Cardiac output was measured by the indicator dilution method using indocyanine green. Injections were made through a polyethylene catheter inserted approximately $10 \mathrm{~cm}$. centrally through a venipuncture in the antecubital fossa. The arterial dilution curve was recorded from the brachial artery by a Gilford $\dagger$ densitometer, which was calibrated with the known concentrations of dye in the patient's blood at the end of the procedure.

In 10 other patients, the effect of oral medication on the blood pressure was also determined. Blood pressure levels were determined by averaging readings taken four times daily in the hospital, or by measurements made twice daily by the subject himself at home.

\section{Results}

Characteristic effects of the drug. Intravenous injections of doses of $12.5 \mathrm{mg}$. of bretylium tosylate resulted in an immediate but short-lived respiratory

* Established Investigator of the American Heart Association, New York, N. Y.

$\dagger$ Gilford Instrument Company, Oberlin, Ohio. 
stimulation. This was accompanied by vasoconstriction of the skin (FIGURE 1), which lasted 2 to $3 \mathrm{~min}$. And sometimes a sharp elevation in blood pressure, of approximately $20 / 10 \mathrm{~mm}$. Hg. followed. These changes recurred after each successive dose of the same magnitude. At the time of the blood pres-

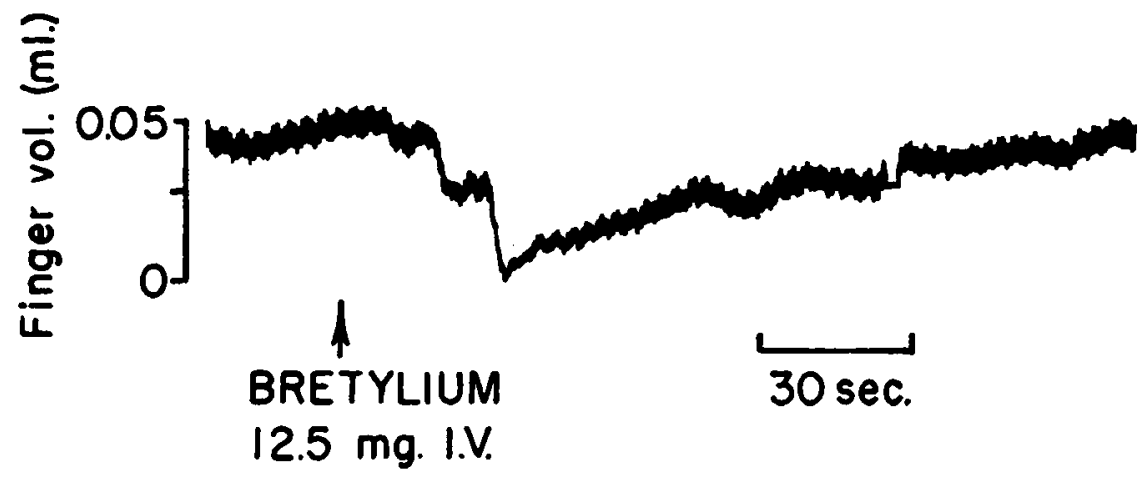

FIGURE 1. Digital plethysmogram showing the effect of an intravenous dose of bretylium.

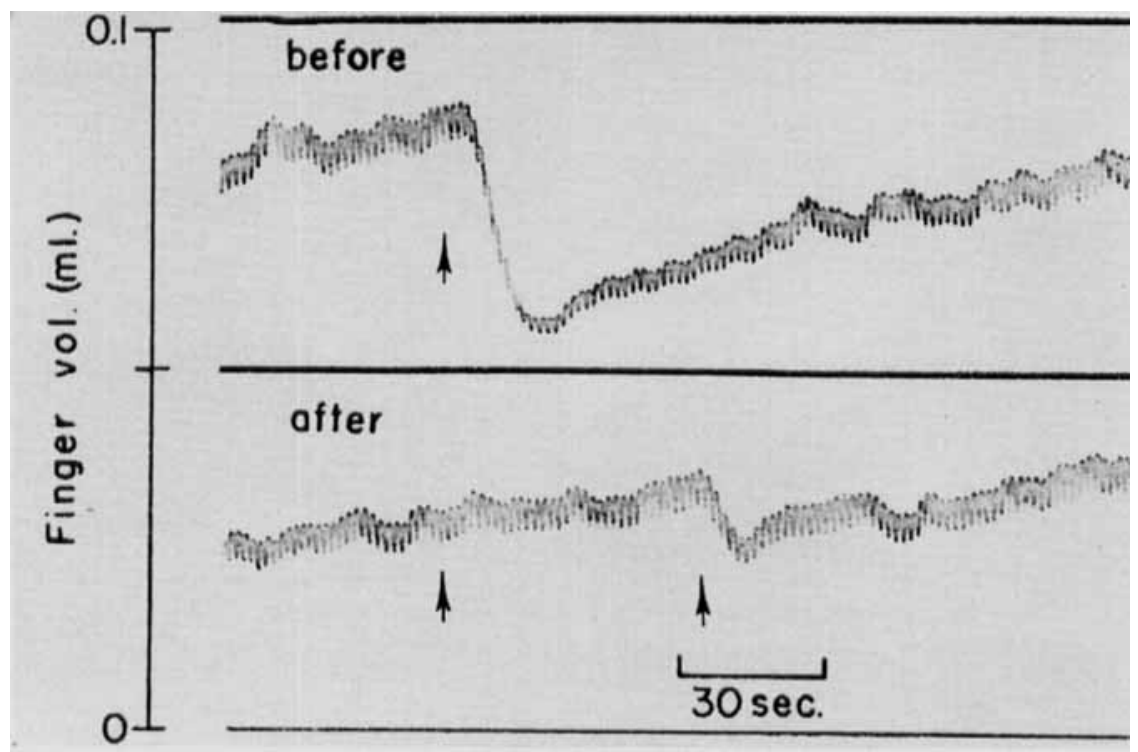

FIGURE 2. Effect of bretylium (100 mg. I.V.) on inspiratory reflex. The arrow indicates onset of deep inspiration.

sure elevation, some degree of sympathetic blockade could be demonstrated by a fall in blood pressure on standing.

In three patients a rise in blood pressure occurred some 6 to 9 hours after the administration of the drug. Two had received the drug intravenously and one orally. In view of the time that had elapsed, it is impossible to be certain of a causal relationship between the rise in pressure and the administration of the drug, but no other explanation could be found for the increase in pressure 
in any of the patients, and it exceeded the random variations in their blood pressure record. Reserpine ( $2.5 \mathrm{mg}$. I.M.) successfully reversed the rise in pressure.

The degree of blockade was assessed by eliciting several constrictive reflexes. The reflex most readily abolished was the vasoconstriction produced in the finger after a deep inspiration (FIGURE 2). A dose of $100 \mathrm{mg}$. intravenously prevented this reflex response in six of the eight subjects studied. Similarly, the overshoot produced by the Valsalva maneuver was abolished in two sub-

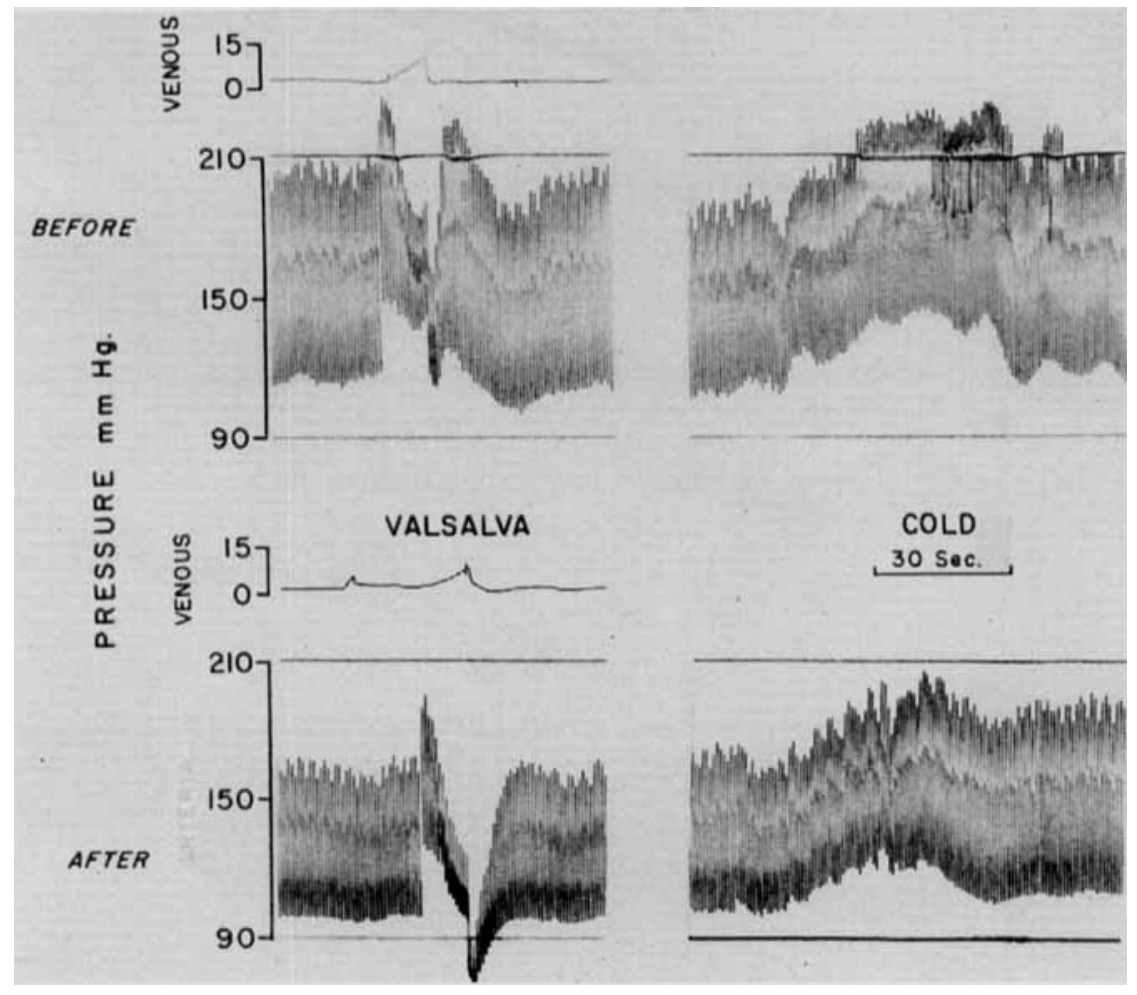

Figure 3. Effect of bretylium (100 mg. I.V.) on the Valsalva maneuver (left) and cold pressor test $($ right).

jects (FIGURE 3). More potent reflexes were not completely suppressed. For example, the average rise in blood pressure produced by the standard cold pressor stimulus (FIGURE 3) was reduced from $55 / 38$ to $30 / 18 \mathrm{~mm}$. $\mathrm{Hg}$.

There were very few side effects produced by parenteral administration of bretylium; apart from the initial constrictive response, the only other effects were occasional flushing of the skin, nasal stuffiness, and injection of the conjunctivae. There were no alimentary or CNS effects.

Effects on the circulation. The most striking peripheral effect of bretylium was an increase in skin temperature of the hands and feet (FIGURE 4), which 
averaged $1.50^{\circ} \mathrm{F}$. for the former and $2.5^{\circ} \mathrm{F}$. for the latter. There was no change in temperature of the trunk. In association with this change there was an average increase of 35 per cent in finger blood flow. The forearm did not participate in this change. The average blood flow rate actually fell from 5.0 to $4.7 \mathrm{ml} . / 100 \mathrm{ml}$. $/ \mathrm{min}$.

The effects of bretylium on the circulation were compared with those of phentolamine in five subjects. Both drugs increased the pulse volume of the

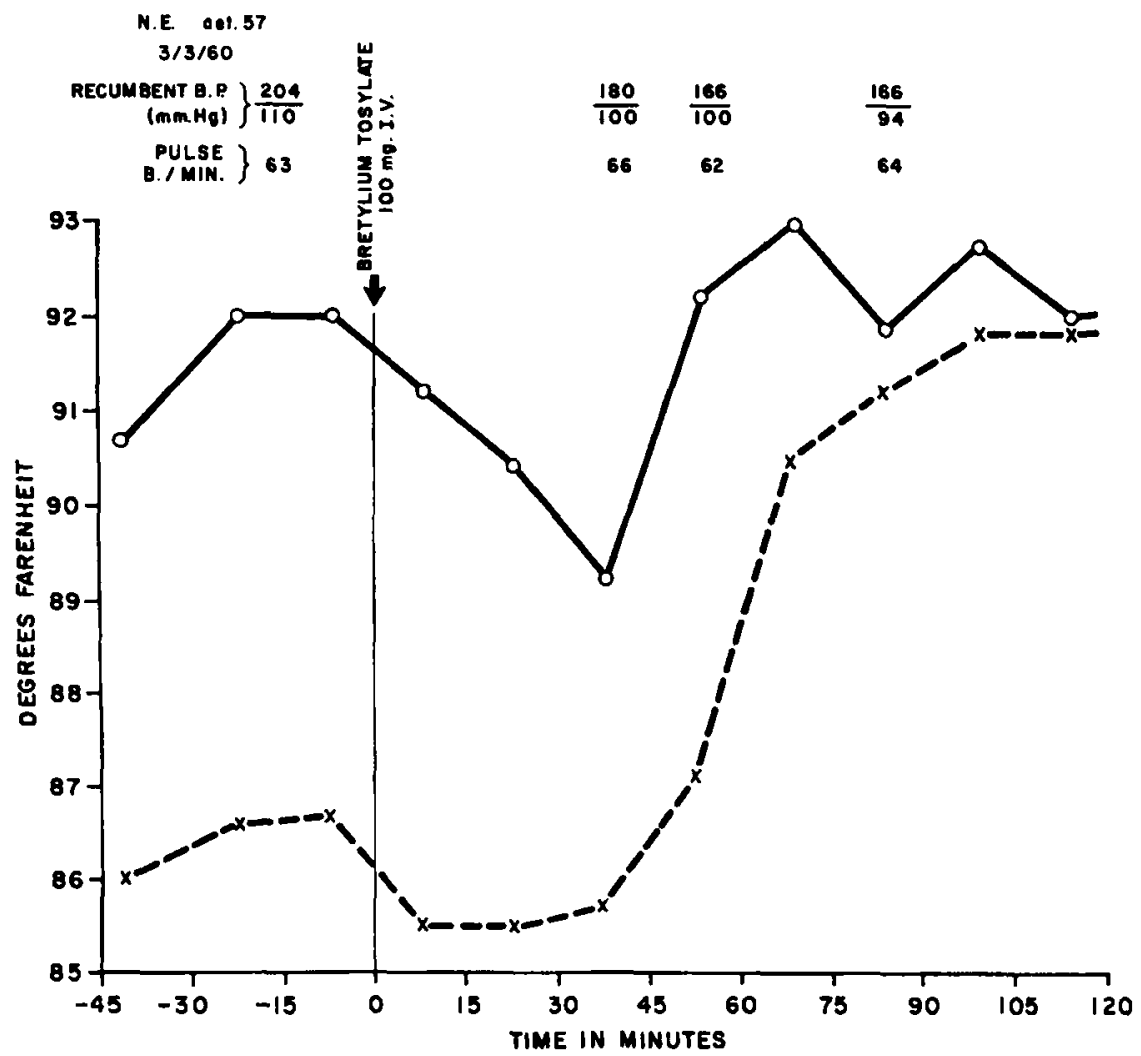

Figure 4. Effect of bretylium tosylate on hand $(o)$ and foot $(x)$ temperatures.

digit and usually abolished the response to a deep inspiration. In addition to this, phentolamine evoked an average increase in forearm flow from 5.3 to $6.3 \mathrm{ml} . / 100 \mathrm{ml} . / \mathrm{min}$, , and in one patient phentolamine increased cardiac output from 5.2 to $6.7 \mathrm{l} . / \mathrm{min}$., while bretylium produced little change.

In the five patients in whom measurements of cardiac output were made there was a slight mean reduction from 5.2 to $4.9 \mathrm{l}$./ min., at which time the mean blood pressure fell from 135 to $130 \mathrm{~mm}$. Hg. Each patient showing a fall in blood pressure had a simultaneous reduction in output, with no change in calculated peripheral resistance.

Effect on the blood pressure. The administration of $100 \mathrm{mg}$. of bretylium 
tosylate intravenously to 17 hypertensive patients in the recumbent position resulted in a small fall in recumbent blood pressure, averaging $14 / 6 \mathrm{~mm} . \mathrm{Hg}$ (TABLE 1). This was accompanied by a slight decrease in heart rate from 77 to $74 \mathrm{beats} / \mathrm{min}$. Records of blood pressure taken after the hemodynamic studies were complete showed a small increase in hypotensive effect with time, the maximal response averaging $22 / 14 \mathrm{~mm}$. $\mathrm{Hg}$ (TABLE 1). The standing blood pressure showed a much greater reduction, with an average of $35 / 19$ $\mathrm{mm}$. Hg. The diastolic fall is an estimate, since the response could not be recorded with accuracy in two patients. The average duration of effect of this dose of bretylium was 10 hours.

\section{TABLE 1}

The Effect of a Single Intravenous Dose (100 Mg. I.V.) of Bretylium Tosylate on the BLOOD Pressure in 17 Hypertensives

\begin{tabular}{|c|c|c|c|c|c|c|}
\hline \multirow{2}{*}{\multicolumn{2}{|c|}{$\frac{\text { Acute effects (within } 60 \mathrm{~min} \text {.) }}{\frac{\begin{array}{l}\text { Initial recumbent pressure and change } \\
(\mathrm{mm} . \mathrm{Hg})\end{array}}{}}$}} & \multicolumn{5}{|c|}{$\begin{array}{c}\text { Later effects } \\
\text { Maximum pressure change (mm. } \mathrm{Hg} \text { ) }\end{array}$} \\
\hline & & \multicolumn{2}{|c|}{ Recumbent } & \multicolumn{2}{|c|}{ Standing } & \multirow{2}{*}{$\begin{array}{l}\text { Duration } \\
\text { (hours) }\end{array}$} \\
\hline Systolic & Diastolic & Systolic & Diastolic & Systolic & Diastolic & \\
\hline $\begin{array}{l}170(+4) \\
200(-34) \\
172(-12) \\
198(-8) \\
235(-10) \\
150(0) \\
185(-16) \\
220(0) \\
195(-14) \\
220(-10) \\
205(-81) \\
230(-38) \\
145(-5) \\
220(-26) \\
208(+6) \\
196(+6) \\
174(0)\end{array}$ & $\begin{aligned} & 98(0) \\
& 110(-16) \\
& 111(-1) \\
& 120(0) \\
& 98(-2) \\
& 100(0) \\
& 116(-10) \\
& 130(0) \\
& 118(-8) \\
& 108(-3) \\
& 138(-58) \\
& 124(-20) \\
& 100(+10) \\
& 120(+6) \\
& 110(0) \\
& 116(+8) \\
& 134(-6)\end{aligned}$ & $\begin{array}{r}-10 \\
-45 \\
-12 \\
-8 \\
- \\
0 \\
-20 \\
-20 \\
-30 \\
-20 \\
-80 \\
-60 \\
0 \\
-30 \\
-5 \\
-10 \\
-5\end{array}$ & $\begin{array}{r}-10 \\
-20 \\
-12 \\
0 \\
-0 \\
-10 \\
-15 \\
-15 \\
-10 \\
-50 \\
-34 \\
0 \\
-20 \\
0 \\
-10 \\
-10\end{array}$ & $\begin{array}{l}-15 \\
-52 \\
-40 \\
-30 \\
-15 \\
-60 \\
-40 \\
-20 \\
-30 \\
-90 \\
-18 \\
-40 \\
-5 \\
-40 \\
-25\end{array}$ & $\begin{array}{l}-10 \\
-30+ \\
-20 \\
-5 \\
-5 \\
-26 \\
-15 \\
-30 \\
-30 \\
-11+ \\
-18 \\
-30 \\
-5 \\
-20 \\
-20\end{array}$ & $\begin{array}{l}6 \\
8.5 \\
18 \\
3 \\
6 \\
6 \\
11 \\
8 \\
12 \\
10 \\
10 \\
14 \\
9 \\
8 \\
12 \\
16\end{array}$ \\
\hline Av. $196(-14)$ & $115(-6)$ & -22 & -14 & -35 & -19 & 10 \\
\hline
\end{tabular}

Only four patients showed a fall in pressure of $10 \mathrm{~mm} . \mathrm{Hg}$ or more in systolic and diastolic levels in the recumbent position, and in one of these the fall was $81 / 58 \mathrm{~mm}$. $\mathrm{Hg}$, reducing his pressure to $124 / 80 \mathrm{~mm}$. Hg. This subject was also unusually sensitive to a ganglion-blocking agent. However when a second test with the same dose of bretylium was made some days later, the fall in pressure was only $12 / 8 \mathrm{~mm}$. $\mathrm{Hg}$, and the resulting level or "floor" of pressure was higher: $156 / 96 \mathrm{~mm}$. $\mathrm{Hg}$.

Effects of oral medication. In 10 patients, studies of the effect of oral administration of bretylium showed that the effective dose varied from 600 to $3200 \mathrm{mg}$./day. The average fall in pressure at optimum dosage was $11 / 13$ $\mathrm{mm} . \mathrm{Hg}$ in the recumbent position, and $32 / 22 \mathrm{~mm}$. $\mathrm{Hg}$ in the standing position (TABLE 2). 


\section{Conway: Clinical Pharmacology of Bretylium Tosylate 961}

The effect on the standing pressure was greater in the morning than in the evening. In addition to dizziness, presumably usually related to orthostatic hypotension, several patients noticed a sensation of extreme fatigue on arising, which passed off in the course of the morning. Tolerance to the drug was noticed in the first 2 to 3 weeks of medication, but this was not troublesome since individual titration of dosage was required. Other side effects have consisted of nasal stuffiness, injection of the conjunctivae, and vague abdominal discomfort. One patient had pain in the parotid gland on salivation.

Further studies to be reported elsewhere ${ }^{4}$ have shown that the effect of bretylium on the blood pressure is very similar to that achieved by ganglion blockers. Some patients who respond to one type of drug, however, may be resistant to the other.

TABLE 2

The Effect of Oral Administration of Bretylium Tosylate on the BLoOd Pressure

\begin{tabular}{|c|c|c|c|c|c|c|}
\hline \multirow{2}{*}{ Patient } & \multicolumn{2}{|c|}{ B. P. without (H) } & \multicolumn{3}{|c|}{ B. P. on bretylium tosylate } & \multirow{2}{*}{$\begin{array}{c}\text { Duration } \\
\text { (days) }\end{array}$} \\
\hline & $\underset{(\mathrm{mm} . \mathbf{H g})}{\text { Lying }}$ & $\begin{array}{l}\text { Standing } \\
\text { (mm. Hg) }\end{array}$ & $\begin{array}{l}\text { Final dose } \\
\text { (mg./day) }\end{array}$ & $\underset{(\mathbf{m m} . \mathbf{H g})}{\text { Lying }}$ & $\begin{array}{c}\text { Standing } \\
(\mathrm{mm} . \mathrm{Hg})\end{array}$ & \\
\hline $\begin{array}{c}1 \\
2 \\
3 \\
4^{*} \\
5 \\
6 \\
7 \\
8 \\
9 \\
10^{*}\end{array}$ & $\begin{array}{l}200 / 120 \\
145 / 100 \\
190 / 120 \\
200 / 140 \\
210 / 130 \\
220 / 150 \\
220 / 160 \\
186 / 120 \\
170 / 110 \\
188 / 123\end{array}$ & $\begin{array}{l}190 / 120 \\
145 / 100 \\
190 / 120 \\
170 / 130 \\
200 / 125 \\
190 / 120 \\
190 / 150 \\
164 / 128 \\
160 / 100 \\
198 / 144\end{array}$ & $\begin{array}{r}1500 \\
1600 \\
600 \\
800 \\
600 \\
1500 \\
1100 \\
800 \\
900 \\
3200\end{array}$ & $\begin{array}{l}200 / 110 \\
145 / 105 \\
190 / 115 \\
160 / 120 \\
190 / 105 \\
200 / 125 \\
186 / 133 \\
188 / 122 \\
191 / 100 \\
174 / 108\end{array}$ & $\begin{array}{l}155 / 100 \\
135 / 100 \\
120 / 90 \\
120 / 90 \\
160 / 90 \\
160 / 110 \\
167 / 132 \\
137 / 95 \\
163 / 90 \\
181 / 125\end{array}$ & $\begin{array}{r}5 \\
6 \\
6 \\
9 \\
13 \\
14 \\
30 \\
30 \\
60 \\
75\end{array}$ \\
\hline Average & $193 / 127$ & $180 / 124$ & 1260 & $182 / 114$ & $148 / 102$ & 25 \\
\hline
\end{tabular}

* Two patients received chlorothiazide $(1 \mathrm{gm}$./day) throughout the period of the test.

\section{Conclusion}

The initial vasoconstrictor effects of bretylium are almost certainly the result of local release of catecholamines, since they have been shown to occur after intra-arterial infusions of bretylium. ${ }^{l}$ Lloyd Beck, in the Department of Pharmacology at the University of Michigan, has shown that the pressor response can be almost completely eliminated in dogs after reserpine has been used to deplete the peripheral stores of norepinephrine. The rise in pressure is also greatly enhanced by a ganglion-blocking drug. Furthermore, Beck has shown that the constrictive response may occur after the effect of direct sympathetic nerve stimulation has been blocked. This is an agreement with the clinical finding that postural hypotension may be elicited during the pressor response to the drug. It seems likely, therefore, that the release of norepinephrine is a peripheral effect occurring distally to the interruption of transmission in the sympathetic nerve fibers.

Bretylium, in the dose used in this study, was adequate to block some con- 
strictive reflexes, but the response to the cold pressor test was not abolished. Since bretylium does not block the output from the adrenal medulla, it is possible that some sympatho-adrenal responses might remain even if the dose of the blocking agent were able to block neural transmission completely. The pattern of the changes in the peripheral circulation, manifested by an increase in flow to the hands and feet and little change in the forearm circulation, were similar to those observed with ganglion-blocking agents tetraethylammonium ${ }^{5}$ and hexamethonium. ${ }^{6.7}$ Apart from the initial vasoconstriction, bretylium did not appear to produce any effects that could not be attributed to blockade of sympathetic activity. For this reason it will be an invaluable tool in the study of the activity of the sympathetic nervous system in man, and will be of great value in assessing the activity of this system in hypertension.

In most recumbent hypertensive patients the fall in pressure caused by bretylium was negligible. Similarly, there was practically no change in heart rate. In those subjects in whom a fall in recumbent blood pressure occurred, a reduction in cardiac output was also observed. For the majority of hypertensives it seems unlikely that the sympathetic nervous system plays an important role in the etiology of hypertension. An occasional patient was seen in whom an unexpectedly large fall in pressure occurred; these patients will require further study.

The effect of oral medication, like that seen with parenteral administration, was mainly on the standing blood pressure. A small change was seen in the recumbent level, of magnitude similar to that seen after parenteral administration of the drug. The effective dose varied from 600 to $3200 \mathrm{mg}$./day. The drug produced a considerably greater effect on the blood on arising in the morning. The reason for this is unknown. Patients who have experienced low levels of pressure in the morning have either complained of dizziness and fainting, or of extreme lassitude. Since the blood pressure may fall to quite low levels without the presence of other warning side effects, this drug should be used with care in patients with cerebral or coronary artery disease.

In conclusion, bretylium provides a useful opportunity for the production of chemical sympathectomy in man which is symptomless if the patient remains in the recumbent position. On standing there is a profound fall in blood pressure. This action provides the basis for the use of bretylium in hypertension. Although the mode of action is nonphysiological and varies with posture throughout the day, it is, nevertheless, of great value in the treatment of patients with severe hypertension in whom simpler drugs, such as chlorothiazide and reserpine, have not effected an adequate reduction in pressure.

\section{Summary}

Bretylium tosylate in I.V. doses of $100 \mathrm{mg}$. produces blockade of some sympathetically mediated reflexes and a diminution of others. It results in an increase in blood flow to the hands and feet, but not to the forearm. The effect on the recumbent blood pressure is quite small, but marked postural hypotension always occurs. 
Oral medication likewise produces its main effect on the standing pressure, and this is greater in the morning than evening levels.

\section{Acknowledgment}

I am indebted to Stanley T. Bloomfield, of Burroughs Wellcome Company, Tuckahoe, N. Y., for the supplies of bretylium tosylate (Darenthin) used in this investigation.

\section{References}

1. Boura, A. L. A., A. F. Green, A. McCourbrey, D. R. Lawrence, R. Moulton \& M. L. Rosenhery. 1959. Darenthin: Hypotensive agent of new type. Lancet. 2: 17.

2. Boura, A. L. A. \& A. F. GREEN. 1959. The actions of bretylium: Adrenergic blocking and other effects. Brit. J. Pharmacol. 14: 536.

3. WHITNEY, R. J. 1953. Measurement of volume changes in human limbs. J. Physiol. 121: 1 .

4. Conway, J., P. Lauwers \& S. W. Hoobler. Sympathetic blocking agent, bretylium tosylate (Darenthin), in the treatment of hypertension. J. Lab. Clin. Med. In press.

5. Hoobler, S. W., S. D. Malton, H. T. Ballantine, JR., S. Cohen, R. B. Neligh, M. M. PeEt \& R. H. Lyons. 1949. Studies on vasomotor tone. The effect of tetraethylammonium on the peripheral blood flow of normal subjects. J. Clin. Invest. 28: 638.

6. Freis, E. D., J. C. Rose, E. A. Partenope, T. F. Higgins, R. T. Kelley, H. W. Schnaper \& R. L. Johnson. 1953. Hemodynamics of hypotensive drugs in man. (III) Hexamethonium. J. Clin. Invest. 32: 1285.

7. Hamitton, M., K. S. Hentey \& B. Morrison. 1954. Changes in peripheral circulation and body temperature after hexamethonium bromide. Clin. Sci. 13: 225. 